Annals of Warsaw University of Life Sciences - SGGW

Land Reclamation No 46 (4), 2014: 309-316

(Ann. Warsaw Univ. Life Sci. - SGGW, Land Reclam. 46 (4), 2014)

\title{
Derivation of consolidation partial differential equations with non-linear flow characteristics on organic soil example
}

\author{
EDYTA E. MALINOWSKA, BARTŁOMIEJ A. BURSA, ALOJZY SZYMAŃSKI \\ Laboratory of Water Centre, Warsaw University of Life Sciences - SGGW
}

\begin{abstract}
Derivation of consolidation partial differential equations with non-linear flow characteristics on organic soil example. Derivation of consolidation partial differential equation with non-linear flow characteristics is proposed. The non-linear flow characteristics are obtained from flow-pump test on organic soil and described with empirical relationship. Several reasons were crucial to perform tests on organic soil. Firstly organic soils are very compressible, so that results in high permeability changes. Even with small stresses organic soil deforms a lot. Secondly road embankments, flood control levees, dykes and dams are very often located on organic soil, so it is important to model deformations under these constructions. Thus to model consolidation process in soft organic soil one should consider as follows: physical and mechanical properties, non-linear stress-strain relationship, non-linear flow characteristics, and creep strains. This paper is focused mainly on non-linear flow characteristics that change with porosity and hydraulic gradient variations.
\end{abstract}

Key words: non-linear flow characteristics, consolidation model, partial differential equation, peat

\section{INTRODUCTION}

The most common organic soft soils located in the engineering depth level is peat. Because of their specific properties such as high vertical and horizontal deformations (which occur during and after the construction period), low initial shear strength (which can causes difficulties to achieve the construction stability), high initial permeability (which changes during the loading) are very problematic issues for construction engineers.

In loaded soft subsoil the significant consolidation process is observed. The consolidation process in peat consist several stages as: primary settlement (immediate and consolidation), secondary and tertiary settlement (creep). Primary settlement is the result of immediate undrained elastic deformation of the subsoil under an applied load. Secondary and tertiary settlement is the consequence of pore water pressure dissipation and creep of material under the effective stresses. Creep depends significantly on time and rheological properties of soil (Den Haan and Edil, 1994, Szymański et al., 2004). The consolidation coefficient is one of the hydraulic-mechanical parameters that should be obtained to estimate the value and the rate of strain of peats. To determinate the coefficient of consolidation it is necessary to find the exact point of the end of consolidation 
settlement; the time of $100 \%$ dissipation of pore water pressure. In peats, the coefficient of consolidation is changeable and hard to determine because the time between consolidation settlement and tertiary settlement (creep) is difficult to be detected.

In order to predict the real time of soil consolidation Terzaghi (1943) linear theory is commonly used. In this approach the coefficient of consolidation is assumed to be constant, whereas, when it comes to the real soil this coefficient varies due to the module of soil volume compressibility changes and permeability changes with growing effective stresses. Taking the coefficient of consolidation as a constant value is a major shortcoming of conventional consolidation theory (Duncan, 1993). When it comes to real soil one should consider high non-linearity of strain and permeability (Hansbo, 1960, 1997, 2003, Swartzendruber, 1962, Davis and Raymond, 1965, Macioszczyk and Szestakov, 1983, Kany and Herrmann 1987, Bartholomeeusen et al., 2001, Teh and Nie, 2002, Xie et al., 2002, Zhuang et al., 2005, Li et al., 2012, Li and Xie, 2013).

Therefore to model the consolidation process in organic soil the non-linear flow characteristics and the non-linear stress-strain relationship should be considered in the calculations. This paper is focused mainly on non-linear flow characteristics that change with porosity and hydraulic gradient variations.

\section{MATERIAL AND METHODS}

The consolidation process depends on distribution of pore water pressure which is connected to permeability. To model the consolidation process under constructions on peats the deformation and pore water pressure distribution should be known.

To obtain the water flow characteristics in soft organic subsoil during laboratory tests it is necessary to model the in situ conditions with consideration of very high water content, fully saturation, very high deformations both in vertical and horizontal direction, unpredictable effective stress and pore pressure range.

Because of very specific peat's properties the optimized method for flow measurement is flow-pump technique, used to model the non-linear flow characteristics. This constant velocity method is proposed as an optimal to obtain repeatability results for in situ values of hydraulic gradient. This is very comfortable and fast method; that in the same apparatus it is able to vent the whole system, fully saturate with back pressure, consolidate, measure the flow velocity. The flow-pump technique assure good test results with the coherence of $82-99 \%$, what is very important to predict and calculate the real amount of vertical and horizontal deformations which depend on consolidation parameters and time (Malinowska et al., 2011).

The flow-pump system consists of triaxial cell and flow-pump, used to model non-linear flow characteristics is presented in Figure 1. 


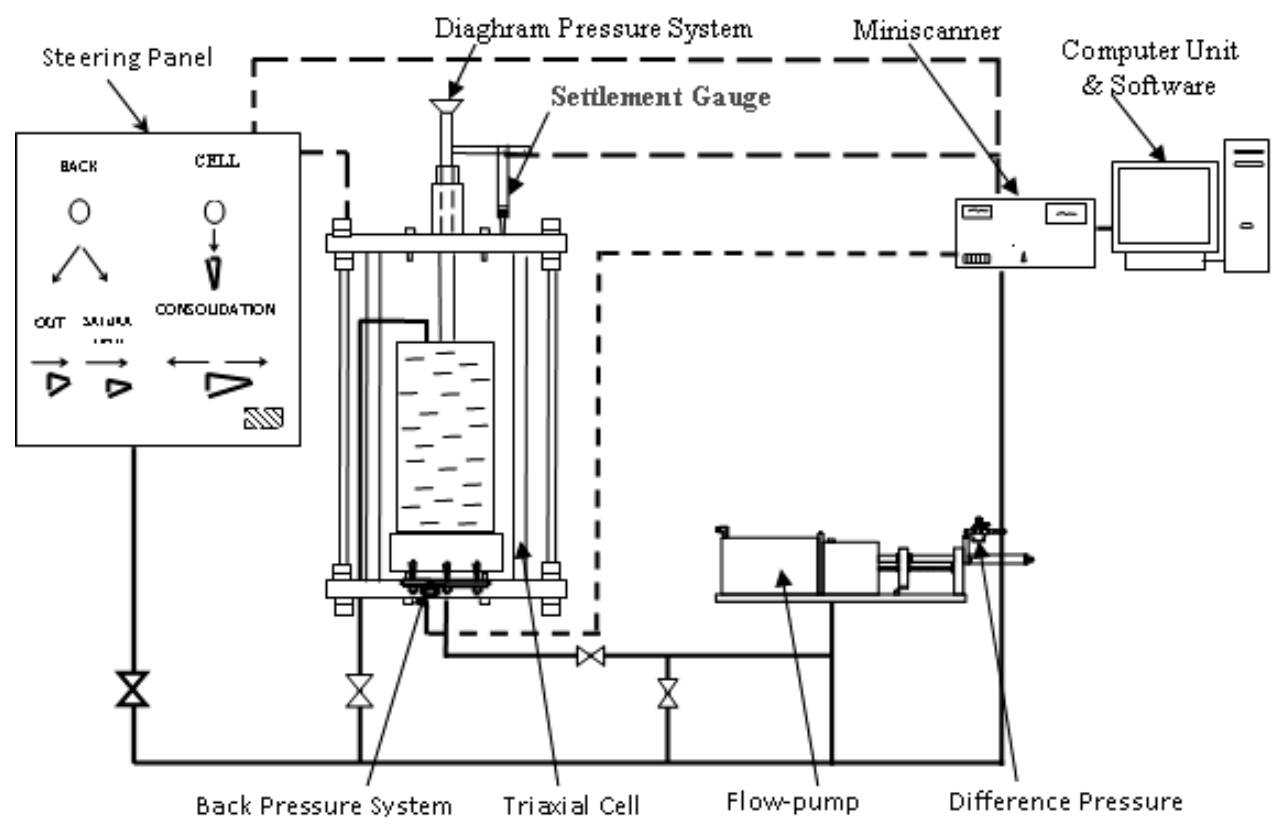

FIGURE 1. The flow-pump system

\section{RESULTS AND DISCUSSION}

The laboratory tests were carried out on undisturbed peats samples taken from Campus SGGW located in the central part of Poland (Table 1).

TABLE 1. Physical properties of peats taken from Campus SGGW tested area

\begin{tabular}{|l|c|}
\hline Physical properties & $\begin{array}{c}\text { Campus } \\
\text { SGGW }\end{array}$ \\
\hline Water content, $w_{n}[\%]$ & 385 \\
\hline $\begin{array}{l}\text { Unit weight of solid particles, } \gamma_{s} \\
{\left[\mathrm{kN} / \mathrm{m}^{3}\right]}\end{array}$ & 15 \\
\hline Unit weight, $\gamma\left[\mathrm{kN} / \mathrm{m}^{3}\right]$ & $10-12$ \\
\hline Dry unit weight, $\gamma_{d}\left[\mathrm{kN} / \mathrm{m}^{3}\right]$ & 2.5 \\
\hline Organic matter content, $I_{o m}[\%]$ & 78 \\
\hline Humification degree, $R[\%]$ & 65 \\
\hline Compressibility index, $C_{c}[-]$ & 1.61 \\
\hline Initial void ratio, $e_{0}[-]$ & 6.7 \\
\hline
\end{tabular}

In order to obtain stress-void ratio relationship the laboratory triaxial tests were performed on undisturbed peat samples in the range of isotropic stress level from 10 to $250 \mathrm{kPa}$. The relationship between effective stress and void ratio is presented in the semi-logarithmic scale in order to obtain linear function (Fig. 2).

Second step was to obtain relationship between pore water flow velocity, effective stress and hydraulic gradient. After conducting the tests and plotting the results, the non-linear flow velocity-hydraulic gradient relationship was observed. So that it was obvious that Darcy's law is not valid (Fig. 3). 


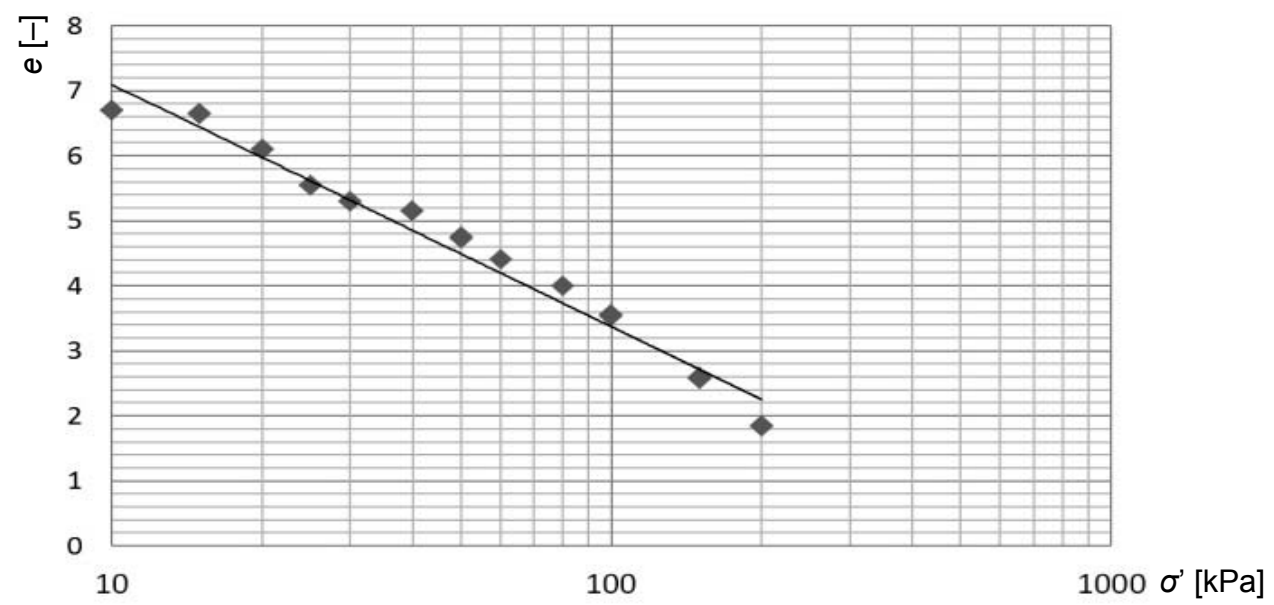

FIGURE 2. The non-linear relationship between effective stress and void ratio

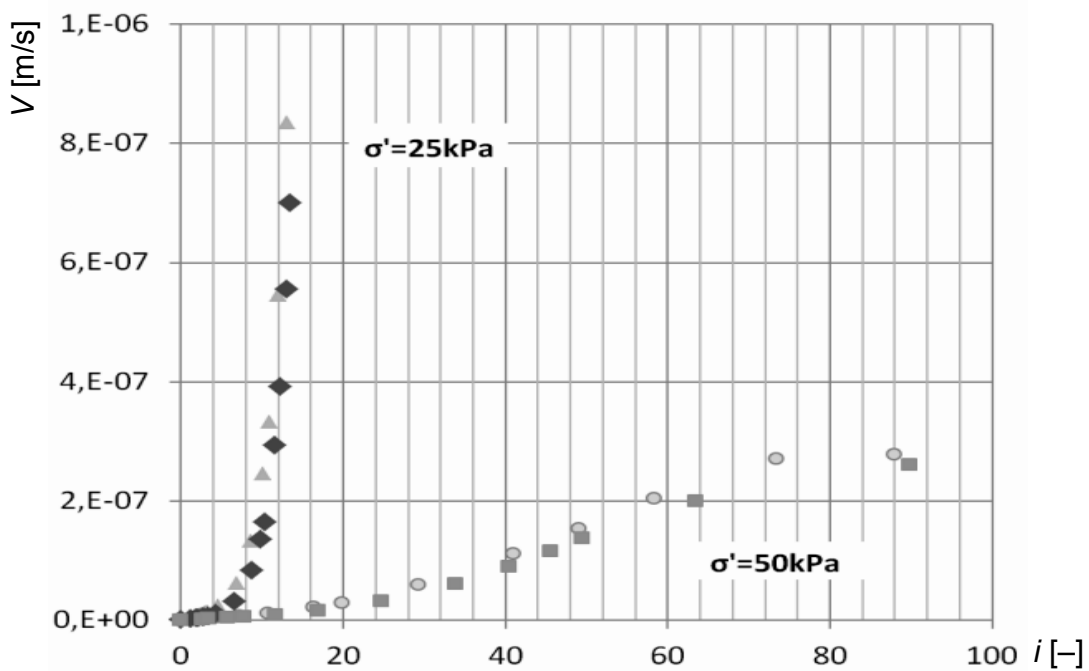

FIGURE 3. The non-linear relationship between flow velocity and hydraulic gradient for effective stress equal 25 and $50 \mathrm{kPa}$

The final step was to create a multivariable function that allows to calculate flow velocity having void ratio and hydraulic gradient known. The equation has been obtained empirically with the consideration of non-linear flow char- acteristics. The characteristics had been obtained from the 350 laboratory tests using flow-pump technique on 14 organic soils samples with 13 different stress-strain conditions (Malinowska, 2001). 
The equation was found in the form of:

$$
v=2 \cdot 10^{-13} \cdot i^{1,2} \cdot e^{5,4}
$$

where:

$v$ - flow velocity;

$i$ - hydraulic gradient;

$e$-void ratio.

The proposed function (1) is plotted in the three-dimensional form (Fig. 4).

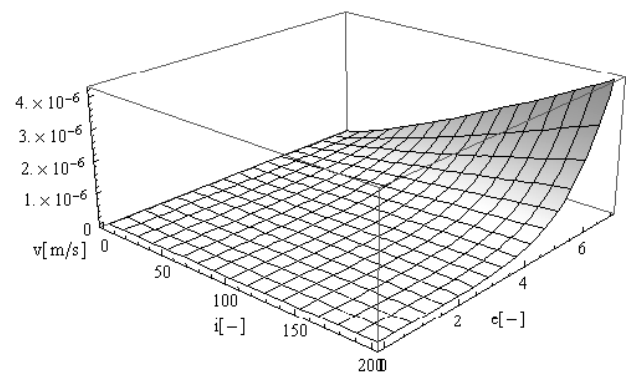

FIGURE 4. The non-linear relationship between effective stress and void ratio

Taking into consideration all of the results obtained from flow-pump test and triaxial test it is obvious that non-linear stress-strain relationship as well as non-linear void ratio-flow velocity relationship were obtained. Moreover Darcy's law is not valid because of non-linear flow velocity-hydraulic gradient relationship.

Many attempts have been made to improve Terzaghi (1943) theory. Many studies were conducted on the one-dimensional consolidation, in which the coefficient of permeability and coefficient of volume compressibility (both related to coefficient of consolidation) vary with the effective stresses and void ratio. Davis and Raymond assumed that decrease of permeability is proportional to decrease of compressibility so the coefficient of consolidation is constant (Davis and Raymond, 1965). Many researches have proposed more realistic non-linear theory with consideration of permeability and compressibility changes (Basak, 1979, Lekha, 2003, Zhuang, 2005). Abbasi et al. (2007) proposed a one-dimensional finite difference approach to solve consolidation model with variable compressibility and permeability. In this paper an attempt to describe the organic soil using non-linear flow velocity relationship between hydraulic gradient and void ratio has been proposed. The flow velocity empirical relation for examined peat has been used.

\section{Basic equation}

Taking into consideration basic continuity equation for one-dimensional consolidation in the form (Lambe and Whitman, 1969):

$$
\left(\frac{1}{1+e_{0}}\right) \frac{\partial e}{\partial t}=-\frac{k}{\gamma_{w}} \frac{\partial^{2} \sigma^{\prime}}{\partial z^{2}}
$$

where:

$k$ - coefficient of permeability;

$\sigma^{\prime}$ - effective stress;

$e_{0}-$ initial void ratio;

$e$ - void ratio.

In this paper the coefficient of permeability is replaced by flow velocity as further described. 


\section{Description of void ratio and permeability changes}

For normally consolidated soils relationship between void ratio and effective stress can be describe as linear function in semi-logarithmic space of e- $\log \sigma^{\prime}$, the slope of this function is called coefficient of compressibility. It can be presented as:

$$
e=e_{0}-C_{c} \log \left(\sigma^{\prime}\right)
$$

where:

$e$ - void ratio;

$C_{c}$ - compression index;

$\sigma^{\prime}-$ effective stress.

Flow velocity non-linear multivariable function of hydraulic gradient and void ratio was determined. The empirical relationship has been found in the form:

$$
v=2 \cdot 10^{-13} \cdot i^{1,2} \cdot e^{5,4}
$$

where:

$v$ - flow velocity;

$i$ - hydraulic gradient;

$e$ - void ratio.

\section{Derivation of governing equation}

Differentiating equation (3) with respect to time:

$$
\frac{\partial e}{\partial t}=-C_{c} \frac{1}{\sigma^{\prime}} \frac{\partial \sigma^{\prime}}{\partial t}
$$

and substituting equation (1) and (4) into equation (2) will result in:

$$
\begin{aligned}
& \left(\frac{1}{1+e_{0}}\right) \cdot C_{c} \cdot \frac{1}{\sigma^{\prime}} \frac{\partial \sigma^{\prime}}{\partial t}= \\
& =\frac{2 \cdot 10^{-13} \cdot i^{1.2} \cdot\left[e_{0}-C_{c} \log \left(\sigma^{\prime}\right)\right]^{5.4}}{\gamma_{w}} \cdot \frac{\partial^{2} \sigma^{\prime}}{\partial z^{2}}
\end{aligned}
$$

$$
\begin{aligned}
& \frac{\partial \sigma^{\prime}}{\partial t}= \\
& =\frac{2 \cdot 10^{-13} \cdot i^{1.2} \cdot\left(1+e_{0}\right) \cdot \sigma \cdot\left[e_{0}-C_{c} \log \left(\sigma^{\prime}\right)\right]^{5.4}}{C_{c} \cdot \gamma_{w}} \times \\
& \times \frac{\partial^{2} \sigma^{\prime}}{\partial z^{2}}
\end{aligned}
$$

considering that $\sigma^{\prime}=\sigma_{q}-u$ and:

$$
i=\frac{\partial u}{\partial z} \cdot \frac{1}{\gamma_{w}}
$$

where:

$\sigma^{\prime}$ - effective stress;

$\sigma_{q}$ - stress due to applied load;

$u$ - pore water pressure;

the final equation was determined:

$$
\begin{aligned}
& \frac{\partial u}{\partial t}= \\
& =\frac{2 \cdot 10^{-13} \cdot\left(1+e_{0}\right) \cdot\left(\sigma_{q}-u\right) \cdot\left[e_{0}-C_{c} \log \left(\sigma_{q}-u\right)\right]^{5.4}}{C_{c} \cdot \gamma_{w}} \times \\
& \times\left(\frac{\partial u}{\partial z} \frac{1}{\gamma_{w}}\right)^{1.2} \cdot \frac{\partial^{2} u}{\partial z^{2}}
\end{aligned}
$$

Solution for the derived non-linear governing equation (8) can be obtained with some of the numerical methods. Solution and discussion of the result is not the aim of this article.

\section{CONCLUSIONS}

In this paper, a non-linear theory has been presented for consolidation of organic soils considering variations in porosity and flow velocity. The new equation has been proposed as a description of the non-linear flow characteristics in 
soft organic soils during the changes of stress.

Based on the presented results the following conclusions can be drawn:

1. When it comes to organic soil, it is crucial to take into account porosity and flow velocity changes during consolidation process.

2. The relationship between void ratio and effective stress is highly non-linear, so it is important to describe it precisely.

3. Flow characteristics are non-linear and depend on porosity and hydraulic gradient.

4. To predict the consolidation process, the non-linear stress-strain and flow characteristics should be taken into the consideration.

5. Derived equation based on empirical flow velocity function can describe consolidation process taking into account non-linear stress-void ratio relation and hydraulic gradient changes.

\section{REFERENCES}

ABBASI N., RAHIMI H., JAVADI A.A., FAKHER A. 2007: Finite different approach for consolidation with variable compressibility and permeability. Computers and Geotechnics 34: 41-52.

BARTHOLOMEEUSEN G., ZNIDARCIC D., HWANG CH., SILLS G.C. 2001: Seepage Inducted Consolidation Test. University of Colorado, Colorado, UK.

BASAK P. 1979: Analytical solution for consolidation of semi-infinite medium with variable permeability. Ind. Geotech. J. 9(3): 201-211.

DAVIS E.H., RAYMOND C.P. 1965: A non-linear theory of consolidation. Géotechnique 15(2): 161-173.
Den HAAN E.J., EDIL T.B. 1994: Secondary and tertiary compression of peat. In: Advances in Understanding and Modelling the Mechanical Behavior of Peat: Balkema, Rotterdam: 49-61.

DUNCAN J.M. 1993. Limitation of conventional analysis of consolidation settlement. Journal of Geotechnical Engineering ASCE 119(9): 1333-1359.

HANSBO S. 1960: Consolidation of clay with special reference to influence of vertical sand drains. Swedish Geotechnical Institute Proceeding 18: 45-50.

HANSBO S. 1997: Aspects of vertical drain design: Darcian or non-Darcian flow. Géotechnique 47(5): 983-992.

HANSBO S. 2003: Deviation from Darcy's law observed in one-dimensional consolidation. Géotechnique 53(6): 601-605.

KANY M., HERRMANN R. 1987: Water motion in soils based on a diffusion theory of mixtures (part 2). Proc. of the 9th Europ. Conf. on Soil Mech. and Found. Eng. Dublin: 1022.

LAMBE T.W., WHITMAN R. 1969: Soil Mechanics. John Wiley \& Sons, New York.

LEKHAK.R., KRISHNASWAMY N.R., BASAK P. 2003: Consolidation of clays for variable permeability and compressibility. Geotech. Geoenviron. Eng. 129 (11): 1001-1009.

Li CH.X., XIE K.H. 2013: One-dimensional nonlinear consolidation of soft clay with non-Darcian. Journal of Zhejiang University Science A. 14(6): 435-446.

Li Ch.X., Xie K.H., Hu A.F., Hu B.X. 2012: One-dimensional consolidation of double layered soil with non-Darcian flow described by exponent and threshold gradient. J. Cent. South Univ. 19: 562-571.

MACIOSZCZYK T., SZESTAKOV W.M. 1983: Prawo filtracji, hydrauliczne charakterystyki strumienia, filtracja ustalona. Dynamika wód podziemnych - metody obliczeń [The filtration law, the characteristics of hydraulic flow, steady filtration. Ground water dynamic - the method of calculation]. Wyd. Geologiczne, Warszawa (in Polish).

MALINOWSKA E.E. 2001: Analiza odkształceń wybranych gruntów organicznych z uwzględnieniem nieliniowych charaktery- 
styk przepływu [The description of soft soils deformations using the nonlinear characteristic of water flow. Doctoral Thesis]. Warsaw University of Life Sciences - SGGW, Warszawa (in Polish).

MALINOWSKA E.E. 2011: Flow-pump technique as a constant velocity method of flow measurement in soft organic soils. Electronic Journal of Polish Agricultural Universities, 14, 4, Civil Engineering \#06.

MALINOWSKA E.E, SZYMAŃSKI A., SAS W. 2011: Estimation of flow characteristics in peat. ASTM Inter. Geotechnical Testing Journal 34, 3: 250-254.

SWARTZENDRUBER D. 1962: Modification of Darcy's law for the flow water in soils. Soil Science 93(1): 22-29.

SZYMANSKI A., SAS W., DROZDZ A., MALINOWSKA E. 2004: Secondary compression in organic soils. Annals of Warsaw Agricultural University - SGGW, Land Reclamation 35: 221-228.

TEH C.I., NIE X. 2002: Coupled consolidation theory with non-Darcian flow. Computers and Geotechnics 20(3): 169-209.

TERZAGHI K. 1943: Theoretical Soil Mechanics. John Wiley \& Sons, New York.

XIE K.H., XIE X.Y., JIANG W. 2002: A study on one-dimentional nonlinear consolidation of double layered soil. Computers and Geotechnics 29(2): 151-168.

ZHUANG Y.C., XIE K.H., LI X.B. 2005: Non-linear analysis of consolidation with variable compressibility and permeability. J. Zhejiang University Sci. 6A(3): 181-187.

Streszczenie: Wyprowadzenie równania różniczkowego czastkowego konsolidacji z uwzględnieniem nieliniowości przeplywu na przyktadzie gruntów organicznych. W artykule zaproponowano wyprowadzenie równania różniczkowego cząstkowego konsolidacji z uwzględnieniem nieliniowości przepływu. Nieliniowe charakterystyki przepływu wyznaczono na podstawie badań flow-pump na gruntach organicznych. Zależność pomiędzy prędkością przepływu wskaźnikiem porowatości i gradientem została zapisana za pomocą równań empirycznych. Analiza wyników badań laboratoryjnych potwierdziła dużą zmienność przepływu wraz ze zmianą porowatości. Wiele budowli, takich jak: nasypy drogowe, obwałowania, zapory i wykopy budowlane, jest bardzo często posadowionych na ściśliwych gruntach organicznych, dlatego właściwe zamodelowanie przebiegu konsolidacji jest bardzo istotne. W tym celu należy wziąc pod uwagę czynniki, takie jak: fizyczne i mechaniczne właściwości gruntu, nieliniową zależność naprężenia i odkształcenia, nieliniową charakterystykę przepływu i pełzanie. W artykule skupiono się na nieliniowych charakterystykach przepływu zmiennych z porowatością i gradientem hydraulicznym. Zaproponowano równanie różniczkowe cząstkowe konsolidacji uwzględniające nieliniowość przepływu w gruntach organicznych.

Słowa kluczowe: nieliniowe charakterystyki przepływu, model konsolidacji, różniczkowe równanie cząstkowe, torfy

\section{MS. received September 2014}

\section{Authors' address:}

Edyta Malinowska

Laboratorium - Centrum Wodne

Wydział Budownictwa i Inżynierii i Środowiska

SGGW

ul. Ciszewskiego 6, 02-776 Warszawa

Poland

e-mail: edyta_malinowska@sggw.pl 